Summer 1996

\title{
Swinburne and Whitman: Further Evidence
}

Terry L. Meyers

College of William and Mary, tImeye@wm.edu

Follow this and additional works at: https://scholarworks.wm.edu/aspubs

Part of the Literature in English, British Isles Commons

\section{Recommended Citation}

Meyers, Terry L., Swinburne and Whitman: Further Evidence (1996). Walt Whitman Quarterly Review, 14(1), $1-11$.

$10.13008 / 2153-3695.1490$

This Article is brought to you for free and open access by the Arts and Sciences at W\&M ScholarWorks. It has been accepted for inclusion in Arts \& Sciences Articles by an authorized administrator of W\&M ScholarWorks. For more information, please contact scholarworks@wm.edu. 


\section{WALT WHITMAN \\ QUARTERLY REVIEW}

Volume 14 | Number 1 ( 1996)

pps. 1-11

\section{Swinburne and Whitman: Further Evidence}

Terry L. Meyers

ISSN 0737-0679 (Print)

ISSN 2153-3695 (Online)

Copyright (C) 1996 Terry L Meyers

\section{Recommended Citation}

Meyers, Terry L. "Swinburne and Whitman: Further Evidence." Walt Whitman Quarterly Review 14

(Summer 1996), 1-11. https:// doi.org/10.13008/2153-3695.1490

This Essay is brought to you for free and open access by Iowa Research Online. It has been accepted for inclusion in Walt Whitman Quarterly Review by an authorized administrator of Iowa Research Online. For more information, please contact lib-ir@uiowa.edu. 


\title{
SWINBURNE AND WHITMAN: FURTHER EVIDENCE
}

\author{
TERRY L. MEYERS
}

The Relations between Walt Whitman and Algernon Charles Swinburne have long attracted interest, in part no doubt because of the apparent virulence with which Swinburne turned away from his early enthusiasm. Swinburne had been one of Whitman's earliest English admirers, from 1859 writing to friends, specifying which of Whitman's poems stimulated his special admiration. In 1868, his exuberance burst into public view as he swept his critical study William Blake towards its close by comparing Blake to Whitman:

I can remember one poet only whose work seems to me the same or similar in kind; a poet as vast in aim, as daring in detail, as unlike others, as coherent to himself, as strange without and as sane within. . . The great American is not a more passionate preacher of sexual or political freedom than the English artist. To each the imperishable form of a possible and universal Republic is equally requisite and adorable as the temporal and spiritual queen of ages as of men. To each all sides and shapes of life are alike acceptable or endurable. From the fresh free ground of either workman nothing is excluded that is not exclusive. The words of either strike deep and run wide and soar high. They are both full of faith and passion, competent to love and to loathe, capable of contempt and of worship. Both are spiritual, and both democratic; both by their works recall, even to so untaught and tentative a student as I am, the fragments vouchsafed to us of the Pantheistic poetry of the East. Their casual audacities of expression or speculation are in effect wellnigh identical. Their outlooks and theories are evidently the same on all points of intellectual and social life. The divine devotion and selfless love which make men martyrs and prophets are alike visible and palpable in each. It is no secret now, but a matter of public knowledge, that both these men, being poor in the sight and the sense of the world, have given what they had of time or of money, of labour or of love, to comfort and support all the suffering and sick, all the afflicted and misused, whom they had the chance or the right to succour and to serve. ${ }^{1}$

And in 1871, Swinburne apostrophized Whitman in a poem in Songs before Sunrise, "To Walt Whitman in America":

O strong-winged soul with prophetic

Lips hot with the bloodbeats of song,

With tremor of heartstrings magnetic,

With thoughts as thunders in throng,

With consonant ardours of chords 
That pierce men's souls as with swords

And hale them hearing along,

Make us too music, to be with us

As a word from a world's heart warm,

To sail the dark as a sea with us,

Full-sailed, outsinging the storm,

A song to put fire in our ears

Whose burning shall burn up tears,

Whose sign bid battle reform. ${ }^{2}$

But by 1887, when he published "Whitmania," Swinburne claimed that "the better qualities discernible" in Whitman were embedded in "voluminous and incoherent effusions"; that he had never regarded Whitman "as a poet or a thinker in the proper sense"; that the "highest literary quality discoverable ... [in Drum-Taps] is rhetoric"; and that, while with "a little more sense and a good deal more cultivation" Whitman might have become "a noticeable orator," as a poet "no amount of improvement that self-knowledge and self-culture" might bring could raise him much higher than Ebenezer Elliott: "the informing principle of his work is not so much the negation as the contradiction of the creative principle of poetry." 3

Now this is good stuff and has allowed scholars from several generations to busy themselves trying to sort out what happened. M. Wynn Thomas has recently drawn attention once more to Swinburne's "notorious attack" in "Whitmania" and has listed the most important articles "on the vexed question of Swinburne's 'defection." 4 But to my mind, an article of some thirty years ago, by William J. Goede, remains the most useful analysis of the question, one that I am now able to supplement with several further pieces of evidence and a suggestion that Swinburne's developing coolness may have manifested a defensive homophobia. Goede's careful study retraces Swinburne's evaluation of Walt Whitman, concluding that what earlier critics had called Swinburne's recantation of earlier enthusiasm, "Whitmania," was actually a "restatement" of views, qualified but not changed. ${ }^{5}$

Swinburne's early admiration for Whitman, as Goede makes clear, was always partial; Swinburne was troubled, he explained in 1867 to William Michael Rossetti, by "the frothy and blatant ebullience of feeling and speech [which] at times is very feeble for so great a poet of so great a people" (Goede, 18). This mixture of praise and caution was clear too even in William Blake, where Swinburne speaks of both Blake and Whitman "at times noisy and barren and loose, rootless and fruitless and informal ... in the main fruitful and delightful and noble, a necessary part of the divine mechanism of things" (Goede, 18). 
And scholars have overlooked another early, and qualified, observation by Swinburne, uttered in March 1868 following a disquisition by James McGrigor Allan on "Europeans, and their Descendants in North America." The Fournal of the Anthropological Society of London ${ }^{6}$ includes an account of a meeting on the evening of March 17, 1868, an account which has never been reprinted. Swinburne remarks broadly on American culture, and makes several comments about Whitman, subtly modulated even in indirect quotation:

Mr. A. C. Swinburne said that not having been in America, he felt a certain reluctance in expressing his opinion on the question, but he must protest against the author's remark that there was no root-point of difference between the literary men of America and England. In his opinion there was a marked difference; and if there were any similarity between the writers mentioned and those of our own country, he thought it was to this extent- that Washington Irving's compositions were Addison and water, and those of H. W. Longfellow, Tennyson and water. But, there was one American poet, who, at least in his opinion, exhibited a special peculiarity not taken from any European model; namely, Edgar Allan Poe, whose works he had always admired as poetical and having an intellectual expression of their own. There might be many better writers in Europe, but he knew of none; and, at any rate, there was undoubtedly a peculiarity in Poe. So much for the south, of which Poe was an example. And with regard to the north, there was Walt Whitman, whose compositions were undoubtedly superior. There was something quite fresh and new in them, whether for praise or dispraise, and a decided originality. His writings had received a slow acceptance even in America; but they were slowly and surely making their way in Europe, and would in time be fairly recognised. America was not so sterile as the author had endeavoured to make out; but, on the contrary, she appeared to have, nay, she had, a new spring of intellectual power. She had amply indicated her power of throwing out original ideas both in literature and in mechanism, which could not in any way be referred to Europe, Asia, Africa, or to any other place. Then there was Emerson, in whom, though it must be admitted there was a certain infusion of European feeling, there was also a distinctive feature not European at all. Literature had been said by some to be the smallest test of intellectuality, and perhaps it was so; but, nevertheless, it was worth while to inquire whence the two men he had cited, who had made their mark in Europe, had derived their peculiarity. In truth it was purely American. Apart from literature, America had solved the great problem - which Europe had not yet succeeded in solving - the problem of democracy. It did not signify what were the particulars in each case, but it was certainly the fact that the question of democracy was agitating all Europe. Russia was being convulsed by it, Spain was heaving with the throes of it, in France it was ready to burst forth instantly - of England he would not speak - all were in the throes of convulsion upon this question, but in America it was solved. In Europe the nations exercised a certain influence over one another; the Anglo-Saxon race could not proceed alone. England could not move without moving Prussia, Prussia without moving Italy, and so on. In his opinion, American intellectuality was an original distinct, native product, not derivative from any other country. (cxlvcxlvi)

Several years later, in a long letter of December 26, 1872, Swinburne wrote an evaluation of some poems sent to him by John Addington Symonds, and took the occasion to mention Whitman and to draw once again some distinctions important to him in clarifying what he admired and what he did not: 
With all my admiration for his great qualities of freedom $\&$ harmony in spirit $\&$ speech I cannot as perhaps you know pretend to enter in full into the Whitmanolatry or Whitmania which seems to beset the esoteric disciple of the first American poet, with whom I am nonetheless proud to be on reciprocal terms of affectionate regard; which deficiency of mine may possibly debar me from quite appreciating or even perhaps fully apprehending the exact scope \& gist of your eloquent hymn of discipleship. Now I trust that I cannot wholly feel the drift \& share the delight of the faith \& rapture of heroic love between friends as expressed here \& in 'Calteus"7; of the three movements of your symphony I decidedly prefer the second to the first \& third which seem to be now $\&$ then to run the risk of becoming (like too much of Whitman's own work) what I should call blatant. A blare of excessive sound \& expression in verse is as bad as a battle of colours that scream \& swear (as French criticism would say) on the canvas. You may think that I am rebuking my own generally acknowledged faults, ${ }^{8} \&$ may be inclined to bid the physician heal himself; but if on coming out of school I take the freedom to give any of my schoolfellows a tap of amicable admonition in passing, I am quite ready to admit with all frankness that I may have well deserved to be horsed in school for the same offence \& flogged till the birch drew blood at every cut.

As this short excerpt suggests, the whole of Swinburne's letter is infused with a rich exploration of sexual proclivities, Swinburne communicating his flagellational obsessions while deflecting Symonds's homoeroticism.

Muted enthusiasm for Whitman is clear too in a letter Swinburne directed to Ramsay Colles the year before publishing "Whitmania." Colles claims in his memoir, In Castle and Court House, that he was "the innocent cause" of Swinburne's writing "Whitmania," an exaggeration of his actual role, which was simply to encourage Swinburne to republish Under the Microscope (1872) with its praise of Whitman. ${ }^{10}$ In any case, Swinburne wrote on November 21, 1886, replying, apparently, to a question Colles posed:

I do not think I ever saw the book on Whitman (Bucke's) ${ }^{11}$ to which you refer: those by Burroughs \& O'Connor ${ }^{12}$ I have read. The former, if rather excessive in its estimate of W.'s merits, is the ablest \& most agreeable study of the subject I know.

\section{Colles responded with enthusiasm on December 12, 1886:}

Your words on Whitman greatly pleased me and I trust you can still say that no opinion expressed by him exists which does not win yr. sympathy.

I enclose some newspaper cuttings which he sent me-which you may not have seen. I trust you will not deem me obtrusive if I beg you will let me know if Bucke's book (which is out of print) wd interest you in the least, that I may have the pleasure of sending it to you-

Three days later, Swinburne replied in terms that could not have pleased Colles: 
Thanks also for the cutting herewith returned: \& for the offer of a loan of Bucke on Whitman, though I will not ask you to send the book, as I should never find time to read it. I am by no means a Whitmaniac, though I still genuinely admire his best earlier work. His indiscriminate admirers have almost wearied \& sickened me (among many others) of the man's very name: \& he has written so much sheer twaddle, of the feeblest \& emptiest kind, that I doubt whether posterity will have patience to pick out his plums from such a mass of indigestible dough.

He then turned his attention to Walter Savage Landor- "a far greater name than any past or present American's."

The climactic incident in Swinburne's evaluation of Whitman was, of course, "Whitmania," which appeared in August 1887 in the Fortnightly Review. Swinburne's language was intemperate:

Mr. Whitman's Eve is a drunken apple-woman, indecently sprawling in the slush and garbage of the gutter amid the rotten refuse of her overturned fruit-stall: but $\mathrm{Mr}$. Whitman's Venus is a Hottentot wench under the influence of cantharides and adulterated rum. Cotytto herself would repudiate the ministration of such priestesses as these. ${ }^{13}$

Such intensity appears to have been provoked most immediately by what Swinburne thought to be excessive praise by his good friend William Michael Rossetti who had, Swinburne wrote to another friend, dared to put Whitman “only a little below Shakespeare!!!!!!” (Goede, 20).

Swinburne's relations with Rossetti were deep and longstanding enough that they were not likely to have been strained for long by a disagreement over Whitman, but Swinburne's housemate, Theodore Watts-Dunton, did go out of his way to reassure him on August 4, 1887, that "I saw William Rossetti and entirely made peace with him anent Whitmania." In his reply (probably August 5, 1887), Swinburne noted his pleasure both that Rossetti was not angered and that Watts-Dunton's understanding of Whitman's stylistic and rhythmic lapses was compatible with his: "I am glad you have made my peace with poor dear old WMR anent Whitman. What you say on the matter of style ( $\&$ rhythm) is as subtly as unanswerably true."

The full text of Watts-Dunton's strictures on style and rhythm has yet to come to light, but one sheet of his letter to Swinburne, dating from August 3 or 4, 1887, does exist and helps illuminate Watts-Dunton's encouragement as Swinburne contemplated Whitman. The fragment begins abruptly, but clearly has to do with Whitman:

entirely devoid of that plastic power without which no poetry can exist. Long before the appearance of Tuppers Proverbs of Philosophy ${ }^{14}$ and long before Warrens 'Lily and the Bee', ${ }^{15}$ there had been scribbled in every village and hamlet in England dramas, epics and lyrics in typographical lines in imitation of certain versions of the Psalms. I, when living in the country have had gravely submitted to me miles, many miles, of such verses by young ladies and by ploughboys, who feeling, in some measure the charm of 'Bible' 
rhythm, have hoped to reproduce it. Not one of these 'writers' could ever have been taught the art of constructing an English verse! The truth however, as Selden pointed out, ${ }^{16}$ 'Bible rhythm' is quite unique as a metrical movement, and is, in a certain sense, the result of a happy accident. The translators, in trying to reproduce in English the bars of the 'sense-rhythm' of the Hebrews failed, but produced a third something partaking of the music of both languages. This is what Whitman Warren Tupper and the rest have hoped to imitate and of course failed.-To suppose that an artist like you or an artist like [Dante Gabriel] Rossetti could ever accept such work as art is absurd[.] Believing in Whitman's sincere utterances of democratic ideas you were willing to accept them as such, but not as art. Whitman, by breaking up his rhapsodies into arbitrary lines, leads the ear to expect the casusu[?] delights of metre and continually baulks it.

One other comment about "Whitmania" seems in order. It has long been known that Whitman refused a chance to reply to Swinburne (Goede, 21), but one published comment seems to have escaped scholarly notice. A reporter approached Whitman for a response, only to be rebuffed with dignity and a mild riposte:

'I hardly know what to think of it. I am rather surprised at Swinburne. I always thought he rather liked my poetry, but perhaps he had tired of it and turned on himself. Shall I reply to it? No, I have nothing to say. I have been strongly urged to do so, but I prefer not to. I have received three despatches from the editor of The North American Review requesting me most earnestly to prepare an answer to the attack for the next number of that publication, but I have positively declined.' ${ }^{17}$

In an unpublished letter of May 5, 1902, Swinburne avoided an opportunity to have printed an early letter to Moncure D. Conway that documented his youthful enthusiasm for Whitman. Conway hoped to print Swinburne's letter of November 7, 1866, ${ }^{18}$ in his Autobiography, Memories, and Experiences. By this time, of course, Swinburne's public estimation of Whitman in "Whitmania" had long been known, and, although he cast his refusal in evasive terms, Swinburne clearly saw no need to complicate it further-or to mitigate it:

I am very sensible of your kindness \& courtesy in sending me the transcript of my old ( $\&$ now comparatively juvenile) letter. I must say frankly that I should much prefer its suppression to its appearance in print. I object on principle to the publication of private letters from living men-unless there is some serious reason for it. And a letter so frankly confidential \& personal as this seems to me rather exceptionally unfit to be given to the public. I should most especially abhor \& recoil from the appearance of Byronic brag \& swagger about my personal relish of swimming $\&$ of the sea.

The only other evidence that I have been able to find of Swinburne's later resistance to Whitman I deduce from a letter he may never have written. Among the Whitman volumes (many inscribed by Whitman) in Swinburne's library at his death were not one but two copies ${ }^{19}$ of Gems from Walt Whitman, both inscribed by the editor, Elizabeth Porter 
Gould, the writer and activist. Gould's letter of July 13, 1904, presenting one of the copies, survives. She salutes "Swinburne's interest in our pioneer poet, Walt Whitman," deduces that "he would like to have a home in his library for my little labor of love in his [Whitman's] behalf," and hopes her letter "will be no intrusion, but rather a pleasant introduction to me who has been loyal to the 'good, gray poet' when others have reviled." In my search through Swinburne's correspondence (some 1600 unpublished letters to and from him survive), I have yet to find that he deigned to reply to Gould's enthusiasm.

The evidence here presented allows some deepening of the story of how, as William Michael Rossetti wrote to a friend in 1884, Swinburne "considerably cooled about Whitman." 20 What stands out, despite the increasing invective, is Swinburne's reasonably consistent appreciation of Whitman for some qualities as well as his disdain of him for others. What is less clear is whether some motive other than critical rigor lay behind Swinburne's adjustment in evaluation. Goede says that Swinburne's "animus was not personal" (20), but I wonder if "Whitmania" was not driven in part by homophobia. Swinburne's own sexual irregularities had been reduced by 1887 to fantasy, and, a number of times, especially after coming under the influence of Watts-Dunton, Swinburne was careful to draw away from earlier suspect associations, as with his repudiation of his friend Simeon Solomon, whose homosexuality led to public opprobrium.

Swinburne's homophobia has been explored in part by John Y. LeBourgeois, who examined the way Swinburne abandoned Simeon Solomon after several men were arraigned for homosexual activities in May 1871. LeBourgeois quotes from a number of letters to show Swinburne's apprehension lest his name be dragged into the affair; he also quotes the Saturday Review to show that Swinburne had some reason to be concerned. Several days after the trial, the Saturday Review opined that "the poetry of Mr. Swinburne and the fictions of some living French novelists deal to a considerable extent with themes which might have been thought to have disappeared with the extinction of Paganism"21 ("pagan" appears to have been a code word for "homosexual" in the latter part of the nineteenth century and beyond). ${ }^{22}$ LeBourgeois concludes that in ditching Solomon, Swinburne had "edged away from the brink of disaster" and begun his "recoil to respectability" (95). Certainly when Solomon was convicted in 1873 of gross indecency in a public lavatory, Swinburne purposefully edged away, even while protesting his affection for a friend he had known since as early as April 1864. ${ }^{23}$ That Swinburne abandoned his usual practice and never republished his July 1871 review of Solomon's "A Vision of Love" speaks volumes about his desire to distance himself from Solomon. 
Swinburne's recoil hardly affected his own licentious behavior during the $1870 \mathrm{~s}$, but it does foreground an attitude towards homosexuality that seems to have intensified in the early 1890 s, as in his denunciation in 1893 of John Addington Symonds as "the Platonic amorist of blue-breeched gondoliers who is now in Aretino's bosom" 24 and whom he referred to the next year as "the late Mr. Soddington Symonds."25 The intensity of Swinburne's antipathy to Symonds can be seen in several unpublished quatrains that date from this period:

\section{Elegy}

There is sorrow in Sodom, \& grief in Gomorrah,

For Addington Symonds that's gone.

There has been no such [arse] lover since Plato, begorra,

As this Oxonicular John.

In Aretino's bosom ${ }^{26}$ now

He Sleeps-a pig who scorned a sow;

The blue backsides of gondoliers

Will wake no more his amorous tears.

Moreover, a squib on Wilde attributed to Swinburne (indeed very likely his) suggests again Swinburne's desire to open some distance between himself and homosexuality:

\section{Oscar Wilde}

When Oscar came to join his God,

Not earth to earth, but sod to sod,

It was for sinners such as this

Hell was created bottomless. ${ }^{27}$

In such a passage as the following from "Whitmania," as Swinburne primly evokes heterosexual relations in speaking of Whitman's poetry, one can sense the desire of a man seeking to station himself on the proper side of an issue:

But under the dirty clumsy paws of a harper whose plectrum is a muck-rake any tune will become a chaos of discords, though the motive of the tune should be the first principle of nature - the passion of man for woman or the passion of woman for man. And the unhealthily demonstrative and obtrusive animalism of the Whitmaniad is as unnatural, as incompatible with the wholesome instincts of human passion, as even the filthy and inhuman asceticism of SS. Macarius and Simeon Stylites. ${ }^{28}$

The language barely conceals its motive.

Finally, in considering Swinburne's later attitude towards Whitman we should recall the increasing pressures on gender roles and sexuality that men in England felt from the 1880s, a pressure illuminated by Elaine Showalter in Sexual Anarchy: Gender and Culture at the Fin de Siècle. ${ }^{29}$ 
Two events in particular probably raised Swinburne's anxiety about his public probity. One was W. T. Stead's dramatic newspaper investigations in 1885 ("The Maiden Tribute of Modern Babylon") of brothels specializing in child prostitution, sadism, and flagellation, all part of Stead's campaign to raise the age of consent for women from thirteen to sixteen..$^{30}$ The other was the 1885 Labouchère Amendment to the Criminal Law Amendment Act making criminal all acts (private as well as public) of "gross indecency" between men.

\section{College of William and Mary}

\section{NOTES}

1 The Complete Works of Algernon Charles Swinburne, ed. Edmund Gosse and Thomas James Wise, 20 vols. (London: William Heinemann, 1925-1927), 16:342-343. The Bonchurch Edition.

2 The Poems of Algernon Charles Swinburne, 6 vols. (London: Chatto and Windus, 1904), 2:120-121.

3 Bonchurch, 15:308, 310, 317, 318.

4 "Whitman in the British Isles," in Walt Whitman and the World, ed. Gay Wilson Allen and Ed Folsom (Iowa City: University of Iowa Press, 1995), 12, 17.

5 "Swinburne and the Whitmaniacs," The Victorian Newsletter, 33 (Spring 1968), 27.

66 (1868), cxxv-cxlvi.

7 The recovery of this heavily inked-out sentence is due to the efforts of Messrs. Higham and Maby, of the University of Bristol Library, who kindly undertook to examine the holograph and a typescript similarly inked out. I am grateful to William Heinemann Ltd. for permission to quote from unpublished materials by Swinburne. This letter is printed with the permission of the University of Bristol Library, where it resides.

Other unpublished letters are quoted with the permission of their holders: the Harry Ransom Humanities Research Center, the University of Texas, which owns Swinburne's letters of November 21 and December 15, 1886, and Ramsay Colles's letter to Swinburne of December 12, 1886, as well as Elizabeth Porter Gould's letter of July 13, 1904; the Berg Collection, the New York Public Library, which owns Theodore Watts-Dunton's letter of August 4, 1887, as well as the fragment of August 3 or 4, 1887; Mark Samuels Lasner, who owns Swinburne's letter dated August 5, 1887; and Columbia University, which owns Swinburne's letter of May 5, 1902. The quatrains on John Addington Symonds are in the Brotherton Collection, Leeds University Library, and are published with permission. 
Let me here record, too, debts owed to my colleague Ken Price and to the agencies that over the years have supported my work on Swinburne-the National Endowment for the Humanities, the American Council of Learned Societies, and the Faculty Research Committee of the College of William and Mary.

8 Swinburne echoes John Morley's criticism of Poem and Ballads (1866), that Swinburne "is like a composer who should fill his orchestra with trumpets, or a painter who should exclude every colour but a blaring red, and a green as of sour fruit" (Swinburne: The Critical Heritage, ed. Clyde K. Hyder [London: Routledge and Kegan Paul, 1970], 26).

9 (London: W. Werner Laurie, 1911), 97.

10 Swinburne's letter of November 11, 1886, to an unidentified correspondent, which I printed in "Swinburne: Four More Letters," Notes and Queries, n.s. 21 (June, 1974), 217, can now be identified as having been addressed to Colles, who then volunteered to transcribe Under the Microscope for Swinburne, who had long been without a copy. Colles wrote Whitman that Swinburne was going to reprint the pamphlet, and says that Whitman asked to receive a copy:

When the article appeared in the 'Fortnightly,' entitled 'Whitmania,' I saw at once that I must not grieve the 'good gray poet' by sending it to him, especially as I was the innocent cause of its having been written, but he insisted, and Mr Horace Traubel tells that Whitman on reading contented himself by asking those present, if Swinburne were 'not the damnedest simulacrum,' and there, so far as Walt was concerned, the matter ended. (97)

11 Richard Maurice Bucke, Walt Whitman, to Which is Added English Critics on Walt Whitman, ed. Edward Dowden (London: Gardner,[1883]).

12 John Burroughs, Notes on Walt Whitman as Poet and Person (1867); William Douglas O'Connor, The Good Gray Poet (1866).

13 Bonchurch, 15:316.

14 Martin Farquhar Tupper proliferated four series of Proverbial Philosophy between 1838 and 1876.

15 The Lily and the Bee: An Apologue of the Crystal Palace (1851; rev. 1854), by Samuel Warren.

16 See The Table Talk of fohn Selden, ed. Frederick Pollock (London: Quaritch, 1927), 11.

17 The remark was reprinted in The Critic (August 27, 1887), 105, from an article (which I have not been able to find) in the "Tribune," presumably the New York Tribune. Whitman's comment in this issue of The Critic is more elaborate than that paraphrased in the issue a week earlier (91-92) and that in the New York Times (August 11, 1887), 1a (though The Critic may be simply embellishing that statement [previously known to scholars]): 
the gay poet said he was surprised at this outburst of the gifted Englishman, and he couldn't understand it. Before passing final judgment on it he was waiting to read the article in the Fortnightly. He did not intend to reply to Swinburne. The editors of the North American Review had sent him three dispatches, urgently requesting an article in reply for their next number, but he had positively declined to furnish it, and he had nothing to say for publication.

18 The letter is in The Swinburne Letters, ed. Cecil Y. Lang, 6 vols. (New Haven: Yale University Press, 1959-1962), 1:207-210.

19 Lots 855 and 856, Catalogue of the Library of Algernon Charles Swinburne in Sale Catalogues of Libraries of Eminent Men, vol. 6, Poets and Men of Letters, ed. John Woolford (London: Mansell, 1972).

20 Letter of January 17, 1884, to Edward Dowden, in Selected Letters of William Michael Rossetti, ed. Roger W. Peattie (University Park: Pennsylvania State University Press, 1990), 460.

21 Quoted in John Y. LeBourgeois, "Swinburne and Simeon Solomon," Notes and Queries, n.s. 20 (March 1973), 94 (LeBourgeois's dating here of a letter from Edward Burne-Jones to Swinburne is wrong, I believe. The letter appears to date from early April 1861).

22 See the discussion in my The Sexual Tensions of William Sharp: A Study of the Birth of Fiona McLeod, Incorporating Two Lost Works, "Ariadne in Naxos" and "Beatrice" (New York: Peter Lang, 1996), 49-52.

23 To the history of the 1873 incident (and Swinburne's reaction) by Simon Reynolds in The Vision of Simeon Solomon (Stroud, Glos.: Catalpa Press Ltd., 1984), 81-86, should be added only an account by Watts-Dunton of his happening to meet Solomon in exile near Torquay (unpublished letter of November 21, 1873, in the Berg Collection, the New York Public Library).

24 "Recollections of Professor Jowett," Bonchurch, 15:250.

25 The Swinburne Letters, 6:74.

26 The sniggering query is Swinburne's.

27 Victorian Verse: A Critical Anthology, ed. George Macbeth (Harmondsworth: Penguin Books, 1986), 295.

28 Bonchurch, 15:315-316.

29 New York: Viking Penguin, 1990.

30 See Raymond L. Schults, Crusader in Babylon: W. T. Stead and the Pall Mall Gazette (Lincoln: University of Nebraska Press, 1972), 128-192. 